INTERDISCIPLINARIA ARCHAEOLOGICA NATURAL SCIENCES IN ARCHAEOLOGY

News and Views

\title{
Application of PIXE Spectrometry in Determination of Chemical Composition in Ilkhanid Silver Coins
}

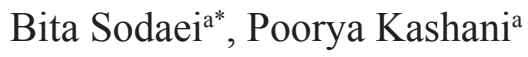 \\ ${ }^{a}$ Department of Archaeology, Islamic Azad University, Varamin, Pishva Branch, Iran
}

\section{ARTICLE INFO}

\section{Article history:}

Received: 18. December 2013

Accepted: 1. July 2013

Keywords:
Ilkhanid
coins
silver
PIXE
X-ray

\begin{abstract}
The study of the elemental composition of silver coins of the Ilkhanid period can help explain the locations and identification of coin mines. It also provides information regarding the economic and political conditions of the time period under study. The aim of this work is to study the chemical composition of certain Ilkhanid coins in order to determine any connection between the mines used for extraction of the silver and the actual silver coins minted at that time. Using the PIXE technique, the metallic elements $\mathrm{Fe}, \mathrm{Cu}, \mathrm{Zn}, \mathrm{As}, \mathrm{Ag}, \mathrm{Au}$, and $\mathrm{Pb}$ were analysed.
\end{abstract}

\section{Introduction}

The study of ancient coins may serve as an indication of the economic and political circumstances at the time of their production. In connection with the iconography, the archaeological issues concern the dating, provenance, technology and authenticity. Coins play an important role in the Iranian cultural heritage. Those coins which belonged to the kings of Ilkhanid were under study.

Using the proton induced X-ray emission (PIXE) technique to study ancient coins is one of the common methods for determining the chemical composition of ancient metals (Smith 2005, 258-264). This technique served to highlight several aspects of the period under study. These findings can be used as a means to deduce information on the economic conditions and the possible sources of metals. Out of various spectroscopic techniques, PIXE is both a useful and nondestructive approach providing archaeologists with highly fruitful information (Guerra 1995; Torkih 2010; Roumie 2010). PIXE has also been applied non-destructively in order to detect trace elements (Constantinescu 1999). PIXE offers maximum sensitivity for elements ranging from approximately Ar to $\mathrm{Zr}$ (Constantinescu 1999; Khademi

"Corresponding author. E-mail: sodaei@iauvaramin.ac.ir
Nadooshan 2011; Hajivalei 2012). The variation in the proton beam energy enables the characterization of the layered structures at the surface (Linke 2004: 127-178). Using PIXE as an analytical tool, we have focused on those metals once used in the Ilkhanid periods in Iran.

\subsection{Historical Background}

In the early $13^{\text {th }}$ century A.D., under the leadership of Genghis Khan, the Mongol Empire expanded out of their original homeland in the eastern zone of the Asian steppe and took over most of Asia. After the death of Genghis Khan, the Empire was divided among his heirs, and consequently Hulagu Khan, Genghis Khan's son, founded the Ilkhanid dynasty of Iran. The Ilkhans consolidated their position in Iran and united the region as a political and territorial entity after centuries of fragmented rule by local dynasties. Hulagu Khan seized the Castle of Alamut, suppressed the Ismaili sect in 1256 and defeated Abbasid Caliph's final army. Al-Musta'sim was captured and executed in 1258, ending 525 years of the Abbasid Caliphate. In 1265 Hulagu Khan died and was succeeded by seven successors: Abagha Khan (1265-1282), Ahmad sultan (1282-1284), Arghun Khan (1284-1291), Gaykhatu (1291-1295), Baydu (1295), Ghazan Khan (12951304), Oljeitu (1304-1316), and Abu Said (1316-1335). With the death of Abu Said the Ilkhanid dynasty in Iran virtually came to an end (Figure 1) (Spuler 1986; Alizadeh et al. 2002). 


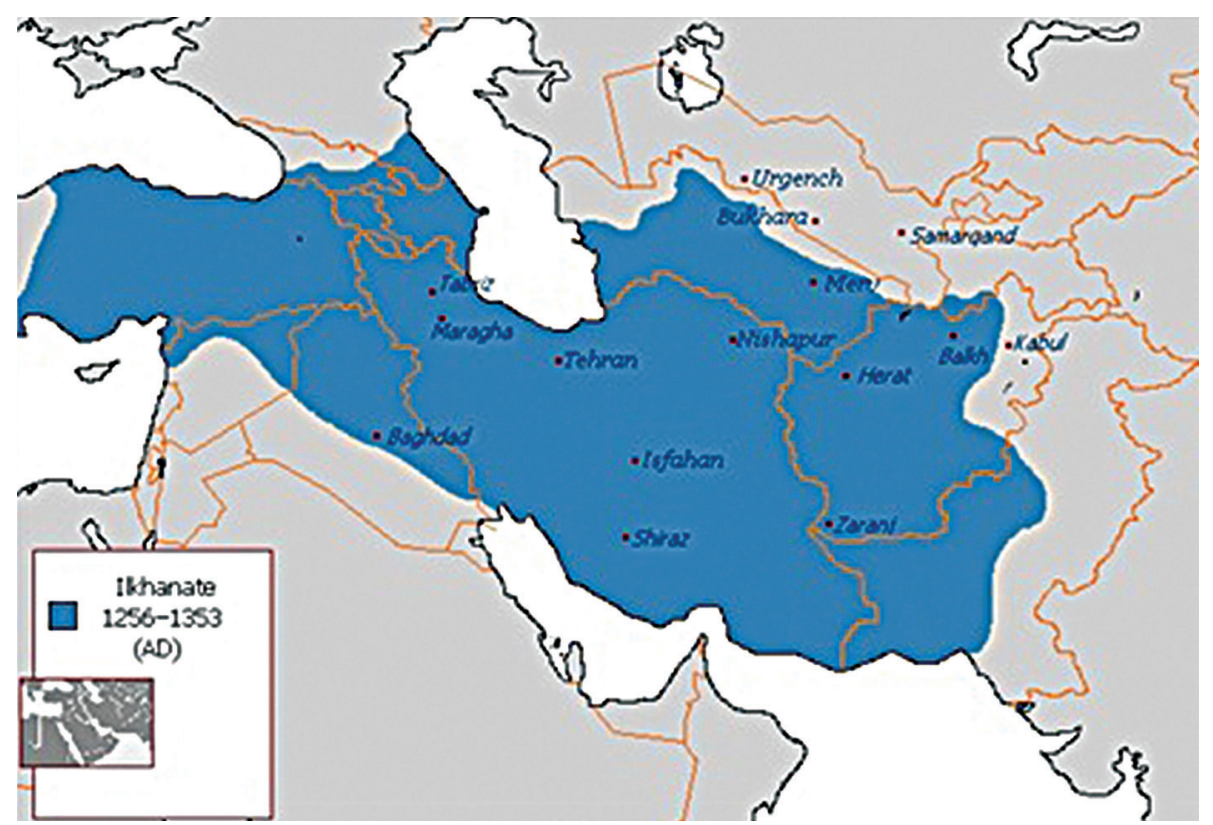

Figure 1. Iran in the Ilkhanid Period.

\subsection{Research Background}

In light of the historical significance of the coins, there was a need to choose a non-destructive method. PIXE is one of the common methods in such cases as it is completely nondestructive, multi-element, fast and sensitive (Guerra 1998). A number of non-destructive spectroscopic methods, including PIXE, have been used to analyse silver objects (Smith 2005).

Firstly, Bacharach conducted research on Sasanian silver coins (Bacharach 1972) with the results having been consequently compared with those of Rome (Hughes 1979). Meyers (2003) and Gurdus (1967) published two articles on the cupellation technique which was applied to mineral ores as galena in order to obtain $\mathrm{Ag}$ by oxidation of $\mathrm{Pb}$ and $\mathrm{Zn}$. The presence of $\mathrm{Au}$ and $\mathrm{Zn}$ along with $\mathrm{Pt}$, as trace elements, had been reported by both authors. In these cases, trace elements were used to find locations of silver origin during the Sasanian period. It was also mentioned that coin thickness had been determined empirically (Gordus 1967).

When re-melting and re-using operations are carried out, however, the Au contents might not be representative of the provenance. Kontos (2000) has demonstrated that Bi may be present as an indicator for the silver mine location in the case of silver coins from Athens. Guerra (Guerra 1995; 1998;

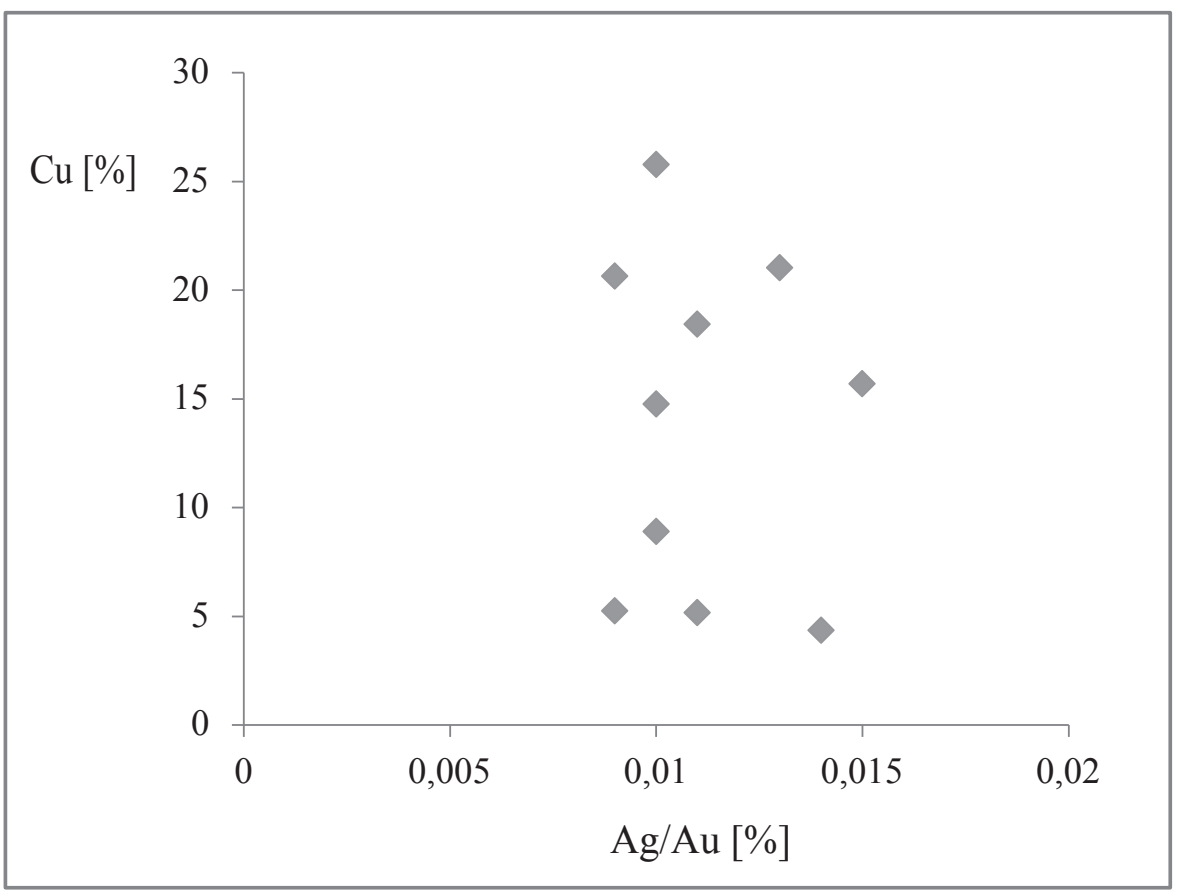

Figure 2. Silver coins of the Ilkhani and the concentration of $\mathrm{Au} / \mathrm{Ag} \mathrm{Vs} . \mathrm{Cu} \%$ with the PIXE technique. 
Table 1. Percentage of elements present in the Ilkhanid coins by PIXE.

\begin{tabular}{|c|c|c|c|c|c|c|c|c|c|c|c|c|c|c|}
\hline Sample & King Name & Weight & $\mathrm{Cl}$ & $\mathbf{C a}$ & $\mathrm{Cr}$ & Mn & $\mathrm{Fe}$ & $\mathrm{Cu}$ & $\mathbf{Z n}$ & As & $\mathbf{A g}$ & $\mathbf{A u}$ & $\mathbf{P b}$ & $\mathbf{A u} / \mathbf{A g}$ \\
\hline 1 & Ghazan & 2.51 & 1.7 & 1.8 & & 0.0 & 0.08 & 5.2 & 0.0 & 0.1 & 89.2 & 1.0 & 0.8 & 0.01 \\
\hline 2 & Ghazan & 3.62 & 2.1 & 1.1 & & 0.1 & 0.1 & 25.8 & 0.4 & & 68.6 & 0.7 & 1.1 & 0.01 \\
\hline 3 & Arghun & 2.31 & 1.2 & 1.1 & & & 0.1 & 21.0 & & & 74.5 & 1.0 & 1.1 & 0.01 \\
\hline 4 & Ghazan & 2.66 & 6.2 & 1.0 & & & 0.3 & 4.3 & & & 85.7 & 1.2 & 1.3 & 0.01 \\
\hline 5 & Ghazan & 2.46 & 4.5 & 1.0 & 0.2 & & 0.8 & 8.9 & & & 83.3 & 0.9 & 0.5 & 0.11 \\
\hline 6 & Ghazan & 2.72 & 8.5 & 1.2 & 0.1 & & 0.8 & 15.7 & & & 71.7 & 1.1 & 1.0 & 0.02 \\
\hline 7 & Arghun & 2.65 & 1.0 & 2.1 & 0.1 & & 2.3 & 5.3 & & & 87.5 & 0.8 & 0.9 & 0.01 \\
\hline 8 & Hulaku & 2.39 & 8.5 & 1.2 & & 0.2 & & 20.7 & 0.4 & & 67.3 & 0.6 & 1.3 & 0.01 \\
\hline 9 & Ghazan & 3.28 & 5.6 & 1.2 & & 0.1 & 0.1 & 14.8 & 0.2 & & 75.8 & 0.8 & 1.4 & 0.01 \\
\hline 10 & Arghun & 2.46 & 7.5 & & & 0.1 & & 18.4 & 0.6 & & 70.6 & 0.8 & 1.0 & 0.11 \\
\hline \multicolumn{3}{|c|}{ SUM } & 39.3 & 11.7 & 0.4 & 0.41 & 4.58 & 121.7 & 1.05 & 0.1 & 703.6 & 8.1 & 9.4 & \\
\hline \multicolumn{3}{|c|}{ AVERAGE } & 4.37 & 1.3 & 0.13 & 0.0 & 0.57 & 13.52 & 0.0 & 0.1 & 78.17 & 0.9 & 1.04 & \\
\hline \multicolumn{3}{|l|}{ STDEV } & 0.38 & 0.38 & 0.06 & 0.0 & 0.76 & 7.97 & 0.0 & 37.0 & 8.38 & 0.19 & 0.28 & \\
\hline \multicolumn{3}{|l|}{ S E } & 0.54 & 0.57 & 0.0 & 0.0 & 0.02 & 1.64 & 0.0 & 0.03 & 28.21 & 0.32 & 0.25 & \\
\hline
\end{tabular}

2004; 2008) revealed that several elements may characterise $\mathrm{Au}$ mines and gold coins. Throughout this study, there has been at attempt to discover the connections between the silver which was used for issuing coins in the Ilkhanid period and the probable sources of metal used at that time.

\section{Material and methods}

\subsection{Experimental set-up}

The analyses were carried out in a van de Graff accelerator at the Atomic Energy Organisation of Iran (AEOL). A $2 \mathrm{MeV}$ proton beam with a current of 2-3 nA was used to bombard the coins. The coins were consequently inserted into a multi-purpose scatter chamber maintained in a high vacuum (10-5 Torr). The emitted characteristic X-rays were detected with an ORTEC Si (Li) detector (FWHM $170 \mathrm{eV}$ at $5.9 \mathrm{keV}$ ). The GUPIX (Campbell et al. 2000) software was employed in order to analyse the obtained spectra. The results are shown in Table 1. Major elements are those contributing with a more than $10 \%$ to the overall composition, minor elements $0.1-10 \%$ and trace elements less than $0.1 \%$ down to detection limits. The overall uncertainty for the PIXE method was $5 \%$ for the major elements; $5-10 \%$ for the minor elements and $15 \%$ for the trace elements. The uncertainties are not only statistical, but also originate from the roughness of the coin surface and from the chemical corrosion and wear to the objects, altering the accuracy of the result (Khademi Nadooshan 2011).

\subsection{Selection of Samples}

Due to the long duration of rule, Ilkhanid silver coins, which were produced during the reign of Hulago Khan, Ghazan Khan and Arghun Khan, were selected. These coins belong to a private collection. All of the coins have been cleaned as follows: they have been kept in 3-5\% formic acid solution for several minutes, scrubbed with a toothbrush and finally cleaned with alcohol soaked cotton.

\section{Results and discussion}

The metallic elements $\mathrm{Ag}, \mathrm{Au}, \mathrm{Pb}, \mathrm{Cu}, \mathrm{Fe}, \mathrm{Cl}, \mathrm{Ca}, \mathrm{Cr}, \mathrm{Zn}$, $\mathrm{Mn}$ and As were detected in the studied coins (Table 1). Approximately half of the silver metals were in all probability produced from lead ores (Tylecote 1962). As in antiquity lead ores were largely exploited to produce silver, the proportion of $\mathrm{Pb}$ must have been relatively high (Hugges 1979). It is commonly accepted that silver metallurgy developed out of lead smelting technology and that the metal silver was extracted from silver-bearing lead ores (Meyer 2003). Recently, there has been a consensus that oxidized ores such as cerussite $\left(\mathrm{PbCO}_{3}\right)$ may have been the primary source for silver in the earliest stages (Craddok 1995). It is also assumed that among the various lead ores argentiferous galena $(\mathrm{PbS})$ was the main source in antiquity for the production of silver (Meyer 2003). The presence of $\mathrm{Pb}$ in the alloys indicates the usage of lead and zinc in minting coins (Uzonyi 2000); and the lower $\mathrm{Pb}$ content in a number of the coins can indicate the quality silver refining process (Tripathy 2010). The results, which are shown in Table 1, can indicate that only the cerussite $\left(\mathrm{PbCO}_{3}\right)$ mine had been explored for extraction of silver in the coins under study. According to Meyers (2003), if the silver was produced from cerussite, the gold content would vary from approximately $0.25 \%$ to $1.0 \%$ which is valid for our case (Harper, Meyer 1981; Meyer 1993). Therefore, one might argue that it corresponds to the ratios which should be found for the ores from which the silver was extracted. In the spectra obtained by the PIXE technique, the $\mathrm{Au}$ is a trace element. Based on the results, a comparison of the $\mathrm{Au} / \mathrm{Ag}$ ratio with the $\mathrm{Cu}$ content of the coins (Figure 1) reveals that one mine of the cerussite type had been explored for production of coins by Ilkhanid metalworkers. Variations in the $\mathrm{Cu}$ amounts in the silver coins of the Ilkhanid kings (Hulako Khan, Ghazan Khan and Arghun Khan) reveal that their reign was faced with an eco-political problem and that $\mathrm{Cu}$ was deliberately added to silver, not only for hardening purposes but also for economic reasons (Tripathy 2010). Coins No. 2, 3, 6, 8, 9 and 10 

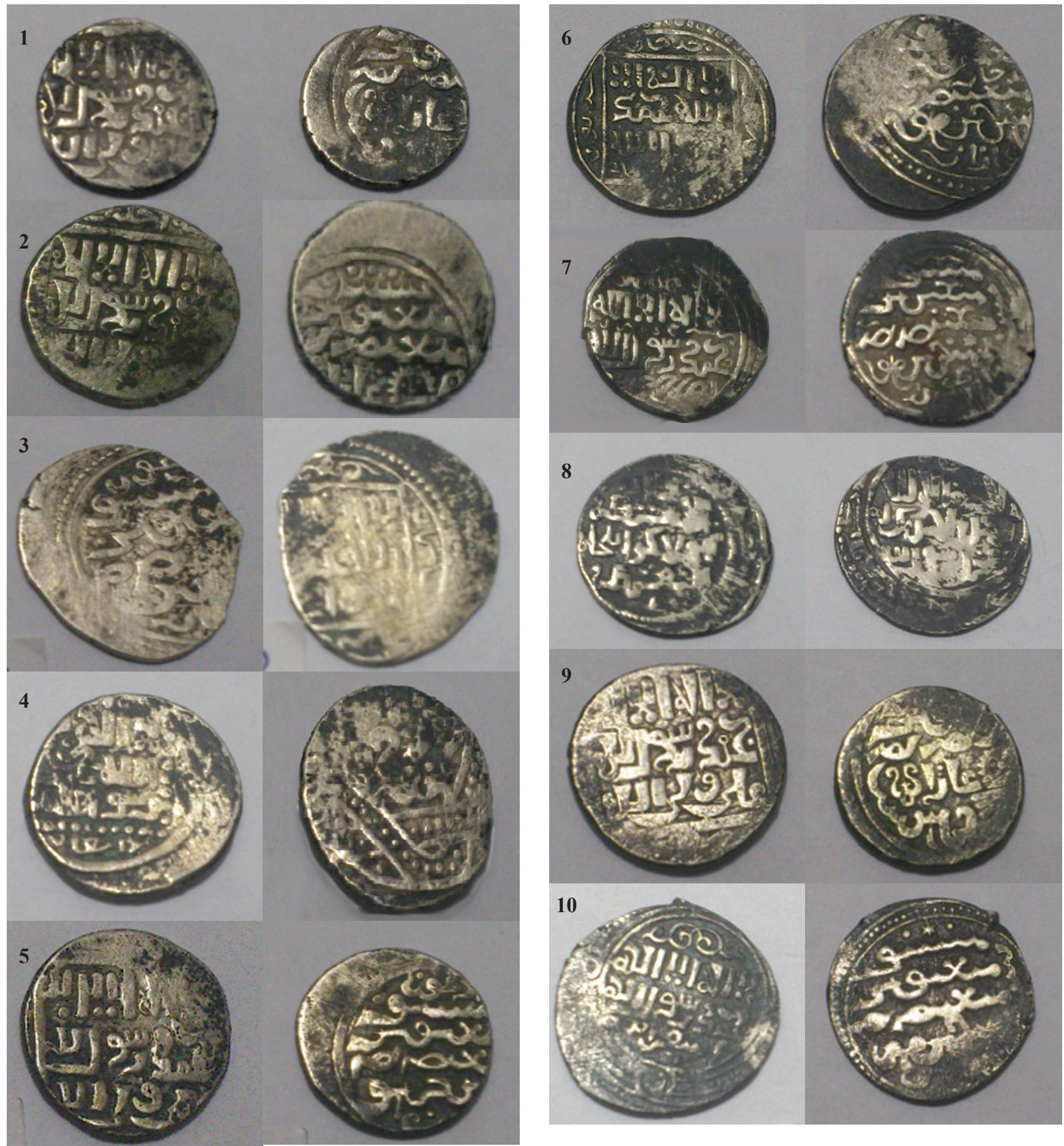

Figure 3. Obverse and reverse sides of Ilkhanid coins (Hulako Khan, Ghazan Khan and Arghon Khan).

have a higher percentage of copper which may indicate a debasement during the reigns of Hulako Khan, Ghazan Khan and Arghun Khan. Coins No. 1, 4 and 7 with less $\mathrm{Cu}$, are indicative of an improved eco- political condition at the time during the Ghazan Khan and Arghon Khan periods.

The presence of $\mathrm{Ca}$ in the cleaned silver coins is due to the fact that its removal was impossible at that time during the metallurgical process. Furthermore, the presence of Fe may be attributed to surface contaminations (Kantarelou 2011; Flament 2004). The results indicate a strong negative correlation between $\mathrm{Ag}$ and $\mathrm{Cu}$, the more the $\mathrm{Ag}$ content, the less will be that of $\mathrm{Cu}$. Moreover, a negative correlation between $\mathrm{Ag}$ and $\mathrm{Pb}$ can also be seen. The obverse and reverse of the Ilkhanid coins are shown in Figure 3. 


\section{Conclusion}

In light of the absence of $\mathrm{S}$ in the analysed Ilkhanid coins, it can be concluded that the extractions of silver were not from Sulfide ores such as galena $(\mathrm{PbS})$. In these cases, extractions seem to have been made from cerussite mineral ores $\left(\mathrm{PbCO}_{3}\right)$. The low amounts of $\mathrm{Pb}$ and $\mathrm{Zn}$ indicate their comparative purity and can indicate that Ilkhanid mineralogy as well as metallurgy was relatively developed. The presence of $\mathrm{Cu}$ in the samples is evidence of the eco-political problems during that era. One can thereby argue that metalworkers had deliberately added $\mathrm{Cu}$ to these silver alloys in order to reduce the costs. Based on this piece of evidence, these problems were more prevalent in the reigns of Hulako Khan, Ghazan Khan and Arghun Khan than Ghazan Khan and Arghon Khan.

\section{Acknowledgements}

We are grateful to Prof. Lamehi-Rachti and Mrs. Oliaei, head of the AEOL Van de Graff Laboratory. We would also like to express our thanks to Mr. Saffar for providing access to his private collection.

\section{References}

ALIZADEH, S., PAHLAVANI, A., SADRNIA, A. 2002: Iran. A Chronological History. Teheran.

BACHARACH, J., ADAON, L. A., GORDUS, A. 1972: The Purity of Sasanian Silver Coins: An Introduction. Journal of the American Oriental Society 92(2), 280-283.

CONSTANTINESCU, B., KENNEDY, J., DEMORTIER, G. 1999: On Relevent PIXE Information For Determining The Compositional Analysis Of Ancient Silver And Bronze Coins. International Journal of PIXE 9(3-4), 487-493.

GORDUS, A. A. 1967: Quantitative Non-destructive Neutron Activation analysis of silver in coins. Archaeometry 10(1), 78-86.

GUERRA, M. F. 1995: Elemental analysis of coins and Glasses. Application and Isotopes 46(6-7), 583-588.

GUERRA, M. F., CALLIGARO, T. 2004: Gold traces to trace gold. Journal of Archaeological Science 31, 1199-1208.
GUERA, M. F, 2004: Fingerprinting ancient gold with proton beams of different energies. Nuclear Instruments and Methods in Physics Research B, 226(1-2), 185-198.

HAJIVALIEI, M., MOHAMMADIFAR, Y., GHIVASI, K., JALEH, B., LAMEHI- RACHTI, M. OLIAY, P., 2008: Application of PIXE to study ancient Iranian silver coins. Nuclear Instruments and Methods in Physics Research B (266), 1578-1582.

HUGHES .M. J., HALL, J. A. 1979: X-ray fluorescence analysis of late Roman and Sasanian silver plate. Journal of Archaeological Science 6(4),321-344.

KALLITHRAKAS-KONTOS. N., KATSANOS, A. A., TOURATSOGLOU, J., 2000: Trace element analysis of Alexander the Greats silver tetradrachms mint in Macedonia. Nuclear Instruments and Methods Research B, 171(3), 342-349.

KANTARELOU, V., AGER, F., EUGENIDOU, D., CHAVES, F., ANDREOU, A., KONTOU, E., RERSPALDIZA, M. M. 2011: X-ray Flourescence analytical criteria to assess the fineness of ancient silver coins: Application on Ptolemaic coinage. Spectrochimica Acta part B: Atomic spectroscopy, Volume 66, Issue 9-10, (681-690).

LINK, R., SCHREINER, M., DEMORTIER, G. 2004: The application of photon, electron and proton induced X-ray Analysis for the identification and characterization of medieval silver coins. Nuclear Instruments and Methods Research B, 226(1-2), 172-178.

MEYERS, P., VAN ZELST, L., SAYRE, E. V. 1979: Interpretation of Neutron Activation Analysis Data of Ancient silver, In: International Conference of Archaeometry and Archaelogical prospecting. Edinburgh, UK.

MEYERS, P. 2003: Production of silver in Antiquity: ore Type identified based upon elemental compositions of ancient silver artifacts, Patterns and Process. In: A Festschrift in Honor of Dr. Edward V. Sayre. 271-288

ROUMIE, M., NSOULI, B., CHALHOUB, G., HAMDAN, M. 2010: Quality control of coins mint using PIXE and RBS analysis. Nuclear Instruments and Methods in Physics Research B (268) ,1916-1919.

SMITH, Z. 2005: Recent development of material analysis with PIXE. Nuclear Instrument and Methods in Physics Research B (240), 258-264.

SPULER, B. 1986: Die Mongolen in Iran. Translated in to Persian by M. Mirafshar, Tehran.

TRIPATHY, B. B., RAUTRY, T., NAYAK, S., RAUTRAY, A. 2010: Elemental analysis of silver coins by PIXE technique. Applied Radiation and Isotopes 68, 454-458.

TORKIHA, M., LAMEHI- RACHTI, M., KAKUEE, V., FATHOLLAHI, A. 2010: An external sub-milliprobe optimized for PIXE analysis of archaeological sample. Nuclear Instruments and Methods in Physics Research B, 268 (9), 1517-1522.

WEBER, G., GUILLAUME, J., STRIVAY, D., GARNIK, H. P., MARCHAL, A., LMARTINOT, L. 2000: Is the External beam PIXE method suitable for determining ancient silver artifact fineness? Nuclear Instrument and Methods on Physics Research B (161-163), 724-729. 
